Alicja Winnicka-Wejs

\title{
THE TEMPORAL, COST AND QUALITY ASPECTS OF HR SSC AND HRO OPERATIONS IN POLAND
}

\section{Abstract}

This paper characterises the dynamically developing sector of modern business services in Poland, focusing particularly on HR Shared Service Centres (HR SSCs) and HR Outsourcing (HROs). The temporal, cost-related, and quality-related aspects of HR SSCs' and HROs' operations in Poland are presented, distinguishing the exogenic and endogenic conditioning of their competitiveness. Moreover, the scope of HR SSCs' operations in Poland is described. Four research hypotheses were formulated for the purpose of the study and were verified by means of the main research method, which is the analysis and critical assessment of the available subject literature and industry reports.

Keywords: sector of modern services for business in Poland, HR Shared Service Centres, HROs, competitiveness of Polish HR SSCs/HROs.

\section{Introduction}

The topic of this paper is the development of HR Shared Service Centres (HR SSCs) and HROs (Human Resources Outsourcing) in Poland. Many organisations, particularly international ones searching for effective and successful business solutions, decide to centralise their personnel processes in one place by creating HR SSCs. If they do not select this option they have the choice of commissioning some or all HR functions in a Human Resources Outsourcing (HRO) arrangement. HR SSCs and HROs are an important component of the modern business-services sector that is developing dynamically in Poland (BPO, SSC, ITO, R\&D). 
The objectives of this study are to describe the modern business-services sector in Poland, to specify the determinants of HR SSCs and HROs in Poland, to present the temporal, cost, and quality aspects of HR SSCs and HROs in Poland and to give an account of the personnel services rendered by HR SSCs in Poland.

The following research questions were posed:

1. What are the characteristic features of the modern business-services sector in Poland?

2. What are the main determinants of the development of HR SSCs and HROs in Poland? What are the endogenic and exogenic conditions influencing Polish HR SSCs and HROs?

3. Which aspects of HR SSCs and HROs (temporal, cost, and quality) will determine their further development in Poland?

4. What kinds of personnel services are rendered in HR SSCs in Poland?

The following research hypotheses were formulated in reference to these questions:

$H_{1}$ : The modern business-services sector in Poland, which has been developing dynamically for the last decade, is characterised by an increase in investments from Western Europe and the USA, the highest employment rate in Central and Eastern Europe, which continues to grow, and high positions in international rankings.

$\mathrm{H}_{2}$ : The exogenic conditions influencing improved competitiveness at Polish HR SSCs are geographical location, incentive policies for foreign investors and labour costs, while the endogenic conditions are the quality of human capital and its management.

$\mathrm{H}_{3}$ : Labour costs, and the quality of human capital and its management, will determine the further development of HR SSCs and HROs in Poland.

$H_{4}$ : Though a range of personnel services are rendered at HR SSCs in Poland, the main focus is on transaction processes.

The main research methods are analysis and critical assessment of the available reference books and analysis of reports from within the individual academic disciplines on the range of services offered by HR SSCs and HROs.

\section{The Modern Business Services Sector in Poland}

The modern business-services sector is one of the fastest growing areas of the Polish economy. Poland is the market leader on rate of employment in the sector in CEE (Central and Eastern Europe: Poland, Czech Republic, 
Hungary, Slovakia, Romania, Bulgaria). In recent years the region has taken on global significance as a business services location. So much so, that it now has 1000 functioning service centres supported by foreign capital from the USA and Western Europe. Without taking into account employment in family companies, employment in the sector in CEE is estimated at 270,000300,000 , which includes over 110,000 people in Poland. It is worth noting that within the last few years the average annual increase in the employment rate in the sector in Poland has remained steady at a level of approximately $20 \%$ and is the most stable of all of the countries in the region. There are now more than 400 service centres with foreign capital operating in Poland. These include Shared Service Centres (SSCs), Business Process Outsourcing (BPO), Information Technology Outsourcing (ITO) and Research and Development Centres (R\&D). The number of investors involved is close to 300. More than $80 \%$ of the centres are in the seven main business-service areas of Kraków, Warsaw, Wrocław, the Tricity (Gdańsk, Gdynia, Sopot), Łódź, the Katowice Conurbation and Poznań (Górecki 2013, pp. 10-11).

The conclusion to be drawn from the records and analyses of PAIiIZ (the Polish Information and Foreign Investment Agency, which for ten years has been publishing a list of the largest foreign investors in Poland, as well as information about direct foreign investments (FDI) grouped according to country of origin of the capital, firms and sectors) is that the modern business-services sector generates a large investment inflow for Poland. For instance, 20 of the 53 projects run in 2012 by PAIiIZ that resulted in a positive investment decision involved the modern business-services sector (Chojnowska-Haponik 2013, p. 6). If we remember that three out of four service centres operating in Poland were established following the country's entry into the European Union in 2004 it will be no surprise to learn that there has been a clear increase in investment inflow since that date (Górecki et al. 2012, p. 13).

Poland is now one of the best locations for service centres based on the business model defined in reference books as "global sourcing" (Corbett 2004). It has been correctly noted in Poland that the sector has only been developing for the last decade and that it now provides more jobs than coal mining (Grzegorczyk 2014a). The Polish export brand has also been spotted abroad, which is demonstrated by a headline that appeared in the New York Times of 23 December 2013: "Future looks bright as Poles fill a niche". Taking the Infosys service centre in Łódź as its example, the article addressed the development of the modern service sector in Poland (Ewing 2013). 
It can be inferred from the available reports that Poland ranks $1^{\text {st }}$ in CEE, $2^{\text {nd }}$ in the whole of Europe, and $6^{\text {th }}$ globally for global outsourcing and offshoring jobs. What is more, the Hackett Group ranks Poland $3^{\text {rd }}$ for global service centre destinations and the country is mentioned in the same breath as China and India as one of the best places for business-services investment projects. The roll of honour does not end there. The latest Everest Group report stated that Poland was the only CEE country to be described as a "mature market" alongside Brazil, China and India. Finally, Poland has been ranked by global managers as the world's $13^{\text {th }}$ best host economy for FDI (Onshore 2013, p. 4).

In Poland, a service centre is defined as an independent organisational unit that executes selected business processes (or their parts) for the benefit of enterprises. To be included in this category it should also employ over 20 people and perform at least one contract of at least one year in duration for the rendering of services (Micek, Działek \& Górecki 2010, p. 14).

The following elements of the modern business-services sector in Poland can be distinguished: Business Process Outsourcing centres (BPOs), which are firms specialising in rendering services mandated by other companies, Shared Service Centres (SSCs), which are separate, independent service units of a given company that run business processes allocated to them, and Research and Development Centres (R\&D Centres), which are specialised companies doing research and development work ordered by other companies or separate company units doing research and development work. This final category also includes Software Development Centres handling advanced computer systems operations (Micek, Działek \& Górecki 2010, pp. 14-15).

Business processes in the field of HCM (human capital management) may be performed by SSCs (HR SSCs) or BPOs (HROs). If processes have been separated and allocated to a branch of the same company we are then dealing with a shared service centre, whereas when the selected processes (or their parts) have been mandated to another company we are dealing with an outsourcing centre.

It is possible in practice, however, to transform a centre into a separate unit that also performs services for external clients. In some cases, companies that wish to focus on their core activities will allocate certain back-office activities to a unit that is subordinate but operates independently. The next step on the way to implementing an outsourcing strategy is the total allocation of processes to an external company that has its own SSC and 
whose exclusive business activity is providing services to business entities (Ziółkiewicz 2010, pp. 67-68).

Taking into account the geographical location of the allocated activity and the form of ownership of the entity performing the mandated business processes, the following types of units may be distinguished: onshore (located within the country), nearshore (located abroad in the same part of the world) and offshore (located abroad in another part of the world) (Majchrzak 2012, p. 48).

In Poland we may talk of nearshoring (e.g. the transfer of services from the countries of Western Europe to Poland) or of offshoring (e.g. the transfer of services from the USA to Poland). According to the Association of Business Service Leaders in Poland (ABSL), one half of the capital invested in the centres comes from European Union companies and almost one third of service centres with foreign capital in Poland are American investments (Górecki et al. 2012, p. 27).

Where shared service centres are concerned, transnational corporations that decide to allocate and delocalise mainly consider Asian countries as destinations, whereas smaller international companies choose new member countries of the European Union (Oczkowska 2012).

\section{The Internal and External Determinants of Competitiveness among HR SSCs and HROs in Poland}

The issues and factors relevant to the development of a new business-services sector in Poland are regularly discussed at national and regional conferences. The conferences organised in Poland for the last five years by ABSL, which is a leading trade organisation representing SSCs and BPOs in Poland, are among the most important events of their kind in Europe (www. absl.pl/conference). ABSL, which was established in 2009 and is composed of more than 80 foreign and Polish investors, works towards changing laws and promoting new business trends and practices. Every year, one session at the European Economic Congress in Katowice is dedicated to "BPO, Shared Services, R\&D Centres" (European Economic Congress 2013, p. 82).

Poland has certain comparative advantages in the area of cost reduction. These are good service quality, which rests on the high calibre of the staff recruited, and investment risk cover, which is connected with the country's economic situation (Pniewski 2008, p. 346). Table 1 shows the most important external and internal determinants of competitiveness among Polish HR SSCs. 
Table 1. The External and Internal Determinants of Competitiveness among Polish HR SSCs and HROs

\begin{tabular}{|c|c|}
\hline \multicolumn{2}{|r|}{ External Determinants } \\
\hline $\begin{array}{l}\text { Geographical } \\
\text { location }\end{array}$ & $\begin{array}{l}\text { - very good connections with major European cities ( } 2 \text { or } 3 \text {-hour flying } \\
\text { time) } \\
\text { - advantageous time zone enabling global communication }\end{array}$ \\
\hline $\begin{array}{l}\text { Business } \\
\text { environment }\end{array}$ & $\begin{array}{l}\text { - strong and thriving economy } \\
\text { - legal system unified with EU norms } \\
\text { - support for investors by the Polish Information and Foreign Investment } \\
\text { Agency (PAIiIZ), the Association of Business Service Leaders (ABSL), } \\
\text { international consulting firms, and local government agencies }\end{array}$ \\
\hline $\begin{array}{l}\text { Inves } \\
\text { incen }\end{array}$ & $\begin{array}{l}\text { - economic policy is a priority sector } \\
\text { - tax exemption in Special Economic Zones } \\
\text { - government funding of new investment projects } \\
\text { - employment (from 3,200 to 15,600 PLN for } 1 \text { place of work) } \\
\text { - support for R\&D (e.g. Applied Research Programme - funding for up } \\
\text { to } 65 \% \text { of R\&D costs) } \\
\text { - local incentives (e.g. tax exemptions on property) }\end{array}$ \\
\hline Job market & $\begin{array}{l}\text { - availability of highly-qualified employees, mainly university graduates } \\
\text { (annual number of graduates is } 435,000 \text { ) } \\
\text { - low labour costs (one of the lowest in Central and Eastern Europe) } \\
\text { - more employees are interested in studying less popular foreign languages } \\
\text { - an increasing number of Erasmus scholarships (e.g. in 2010/2011 - } \\
\text { 14,000 students) }\end{array}$ \\
\hline $\begin{array}{l}\text { Commercial } \\
\text { property } \\
\text { market }\end{array}$ & $\begin{array}{l}\text { - the biggest commercial property market in Central and Eastern Europe } \\
\text { (more than } 6.4 \text { million square metres of office space) } \\
\text { - a wide range of modern office space (Warszawa, Kraków, Wrocław, } \\
\text { Tricity, Katowice, Poznań, Lódź, Szczecin, Lublin, and other new } \\
\text { locations) } \\
\text { - reasonable commercial rents (major markets in Poland: from } 11 \text { to } 16 \\
\text { EUR for } 1 \mathrm{~m}^{2} \text { per month; others: between } 8 \text { and } 11 \text { EUR for } 1 \mathrm{~m}^{2} \text { per } \\
\text { month) }\end{array}$ \\
\hline \multicolumn{2}{|r|}{ Internal Determinants } \\
\hline $\begin{array}{l}\text { Quality } \\
\text { of human } \\
\text { capital }\end{array}$ & $\begin{array}{l}\text { - multilingual human capital - } 34 \text { languages are spoken in Polish Service } \\
\text { Centres } \\
\text { - several thousand employees with some experience in SSCs/BPO } \\
\text { - highly-qualified human capital with specialist knowledge of HR } \\
\text { - employees willing to commute and relocate to develop professionally }\end{array}$ \\
\hline $\begin{array}{l}\text { Human capital } \\
\text { management } \\
\text { standards }\end{array}$ & $\begin{array}{l}\text { - experienced managerial staff with special skills } \\
\text { - good human capital management that improves SSC efficiency }\end{array}$ \\
\hline
\end{tabular}

Source: author's research based on: Górecki (2013, pp. 42-72), Onshore (2013, pp. 5-11), Górecki et al. (2012, pp. 43-72), Czuba (2013), European Economic Congress (2013), Kalinowski et al. (2009), Adamkiewicz-Drwiłło (2010). 
Polish SSC and BPO managers have singled out the importance of the human factor and its quality: "A strong internal market of specialists is one of the greatest competitive advantages of the Polish economy. Thanks to a wide range of highly qualified and multilingual staff, global concerns choose our country as the Service Centre for their strategic projects" (K. Bestry in Czuba 2013).

As well as establishing their own education centres, SSC and BPO companies cooperate with schools and universities to organise specialist and practical courses (Michalska-Sabal et al. 2013, p. 18). The opening of new postgraduate programmes and specialist courses to train and educate SSC specialists is a near necessity for this branch of business in Poland.

There is no doubt that good management of human capital reduces personnel risks (irregularities concerning supply and demand, hiring and firing policies, role division, evaluation, training and motivational systems) that might arise at HR SSCs (Winnicka-Wejs \& Klich 2011, pp. 48-49). The risk of activities being relocated to low cost locations can be minimised through the quality of human capital and by managing that capital well. This is of great importance in terms of the increasing demand for advanced services in years to come when services based on specialist expertise will contribute to the added value of the SSC and BPO sector in Poland.

\section{The Temporal, Cost and Quality Aspects of HR SSC and HRO Operations in Poland}

\subsection{Temporal Aspects}

Poland also finds itself with a temporal advantage with regard to HR SSC and HRO operations. This means that companies are likely to favour the country because its geographical location enables global communication and offers very good connections with the major cities of Europe, which are no more than 2-3 hours' flying time away. The patterns of shift work adopted by such organisations ensure round-the-clock availability despite time differences (e.g. an HR SSC in Kraków - 8.00 p.m., a New York-based company -2.00 p.m.).

The need for improved access time and shorter execution time may be what drives the allocation of personnel functions at SSCs. For instance, the professionalism of HR specialists at SSCs may reduce the time needed to perform particular functions. Appropriate organisation to simplify structures and procedures may not only free internal resources, but also 
allow more time for management. The technology applied can make it possible for staff teams to make more effective use of time.

Where time savings are concerned, the use of SSCs and HROs can shorten processes, ensure that deadlines are met (punctuality) and mean that the development of new products and processes (innovativeness) goes ahead more swiftly.

Time compression strategies, which mean the maximum amount at the lowest costs in the shortest time, may also be applied at HR SSCs and HROs. The instruments of time management may then be the following: SLAs (Service Level Agreements), which cover the question of keeping to deadlines while performing services, the concept of time management as a component of organisational structure and management directed at the fulfillment of certain time norms.

An SSC or HRO organisation may apply the following in the execution of HR processes: an exclusively sequential approach (assuming a certain order of operations, without the possibility of going back), exclusively simultaneous translation (individual sub-processes - such as ones which are partly independent of each other - are executed simultaneously and "meet" only at a certain moment) or a mixed approach (both sequential and simultaneous).

It must be noted, however, that the relevant factors are cost and quality and not the temporal aspects.

\subsection{Costs}

"Service centres are a new trend in Poland" (Klimek-Michno 2012). If this is so, it is due, among other things, to reduced costs. It can be said that cost efficiency is a priority because relocation abroad is determined by cost and efficiency factors (Zorska 2007, p. 35).

The tasks undertaken by SSCs typically involve cost settlement. Customers are charged for this based on the type or volume of the service, income, lack of billing, and market rates (Banachowicz 2008, p. 321).

The benchmarks for fixing remuneration at SSCs may be market rates (the comparative uncontrolled rates method) the cost plus method or the transactional net margin method. The key to allocating personnel costs at SSCs may, for example, be the number of employees (full-time jobs). However, the starting point is to identify direct and indirect costs and to fix the level of market surcharge on costs. It is only then that they can be allocated to particular beneficiaries or customers (Szydłowska 2008, pp. 383-84). 
Table 2. Average Gross Remuneration in EUR* for Employees with a Knowledge of English and HR Processes - Poland, the Czech Republic, and Hungary

\begin{tabular}{l|c|c|c|c|c|c|c|c|c}
\hline \multirow{2}{*}{ HR Process } & \multicolumn{3}{|c|}{ Poland } & \multicolumn{3}{c|}{ Czech Republic } & \multicolumn{3}{c}{ Hungary } \\
\cline { 2 - 10 } & min. & opt. & max. & min. & opt. & max. & min. & opt. & max. \\
\hline $\begin{array}{l}\text { Junior Specialist } \\
\text { (0-1 years of exp.) }\end{array}$ & 675 & 750 & 900 & 720 & 860 & 1000 & 675 & 850 & 1025 \\
\hline $\begin{array}{l}\text { Specialist } \\
(1-2 \text { years of exp.) }\end{array}$ & 850 & 1000 & 1100 & 800 & 960 & 1120 & 850 & 1075 & 1250 \\
\hline $\begin{array}{l}\text { Senior Specialist } \\
(2+\text { years of exp. })\end{array}$ & 1050 & 1200 & 1425 & 1000 & 1300 & 1600 & 1025 & 1175 & 1525 \\
\hline $\begin{array}{l}\text { Team Leader } \\
\text { (5-15 FTEs) }\end{array}$ & 1626 & 1900 & 2225 & 1400 & 1900 & 2400 & 1525 & 1700 & 2025 \\
\hline $\begin{array}{l}\text { Process Manager } \\
\text { up to 50 FTEs) }\end{array}$ & 2250 & 2975 & 3575 & 2000 & 3000 & 4000 & 2025 & 2550 & 3400 \\
\hline
\end{tabular}

* exchange rate: 1 EUR = 4.21 PLN; 1 EUR = 293 HUF; 1 EUR = 25.92 CZK.

Source: Hays Poland (Jasińska 2013, p. 53).

It is certain that labour is responsible for a considerable proportion of the direct costs at HR SSCs and HROs. Poland has an advantage in this respect because its labour costs are lower compared to other countries, which means that it attracts foreign investors. Labour costs in Poland are 50\% lower than in Western Europe, but twice as high as in India (Ewing 2013). Table 2 shows average monthly gross remuneration in EUR in the business-services sector in Poland, the Czech Republic and Hungary for employees with a knowledge of English and HR processes.

\subsection{Quality and Service Level}

Polish HR SSCs and HROs provide high quality services. To reach and maintain these service levels standardisation and benchmarks are required. In practice, objectives are set out in SLAs (Service Level Agreements), while a final settlement is made according to SLAs that include benchmarks. Key Performance Indicators (KPIs), meanwhile, are defined systematically.

The major elements of SLAs are range of services, limits, Service Level Objectives (SLOs), Service Level Indicators (SLIs), penalty charges, optional services, exclusions, reporting, process management, reviews and proofreading (Radło 2011, pp. 136-37). It is also very important to continuously improve and streamline the processes. 
The appropriate HR service level is guaranteed by the employees who have been selected and trained for the HR SSCs and HROs. It is their skills that constitute the quality attributes of human capital in an organisation. Research has shown that honesty, customer orientation, quality orientation, cooperation and verbal communication are attributes that are very important to BPOs and SSCs in Poland. The expectation for the next five years is that candidates for most positions will be able to demonstrate qualities and capabilities such as creativity, a basic knowledge of economics, the ability to influence others, stress management and initiative (Kossowska et al. 2012, p. 78).

The author's review of selected HR SSC job offers in Poland found that employers were looking for very good communication skills, the ability to work as part of a team, consistency, customer orientation and goal orientation. Regardless of the job title, the main requirements are a very good knowledge of the foreign languages specified, the ability to use MS Office and a university degree. Other requirements depend on the particular job title at the HR SSC concerned.

HR SSCs conduct their own searches for new employees but also work with job centres and outsourcing centres that specialise in recruitment for SSCs and BPOs. The following companies were seeking HR specialists in the research period: Lufthansa Global Business Services (LGBS Kraków), Shell Business Service Centre in Kraków, McKinsey \& Company, BD Shared Service Centre in Wrocław, Philips People Services Centre Europe in Piła, Amazon, Philip Morris International Service Centre Europe Ltd, Schneider Electric Polska, UBS Poland Service Centre (UBS PSC), IKEA Business Service Centre in Poznań, Carlsberg ASC and EY Global Services. Some of the job offers were placed by outsourcing centres such as Antal International, Barona, Grafton Recruitment, Hays Poland and Alexander Mann Solutions.

HR SSCs were looking for new employees in the following locations: Katowice, Kraków, Zabierzów, Wrocław, Poznań, Warszawa, Łódź, Gdańsk, Piła and Sady near Poznań.

Table 3 shows the qualifications (qualities and attributes) required for HR SSC job positions in Poland. 
Table 3. Required Qualities and Attributes of Candidates for HR SSCs - Based on Selected Job Offers in Poland

\begin{tabular}{|c|c|c|}
\hline $\begin{array}{c}\text { Job Title } \\
\text { in HR SSCs }\end{array}$ & $\begin{array}{l}\text { Examples of Job Positions } \\
\text { in HR SSCs in Poland }\end{array}$ & $\begin{array}{l}\text { Required Qualities and Attributes } \\
\text { of Candidates for HR SSCs in Poland }\end{array}$ \\
\hline Junior Specialist & $\begin{array}{l}\text { HR SSC Intern, } \\
\text { HR Junior Advisor, } \\
\text { HR Administrator (Junior } \\
\text { Administrator), } \\
\text { Helpdesk Administrator, } \\
\text { Junior Specialist in Training } \\
\text { Management, } \\
\text { HR Consumer Representative, } \\
\text { HR Services Associate, } \\
\text { HR Data Analyst, } \\
\text { Travel \& Expenses Assistant }\end{array}$ & $\begin{array}{l}\text { Very good knowledge of a given } \\
\text { foreign language (English, German, } \\
\text { French, Italian, Dutch, Hebrew, } \\
\text { Slovak, Czech); communication skills } \\
\text { and the ability to work as part of } \\
\text { a team; MS Office skills; university } \\
\text { education or senior students; } \\
\text { customer-oriented; thoroughness, } \\
\text { diligence; good organisational skills, } \\
\text { analytical and problem-solving skills; } \\
\text { positive attitude; experience of Shared } \\
\text { Service or Customer Service will be an } \\
\text { asset; experience in HR management } \\
\text { systems (Oracle, SAP or PeopleSoft) } \\
\text { will be advantageous }\end{array}$ \\
\hline Specialist & $\begin{array}{l}\text { HR Operations Specialist, } \\
\text { HR \& Payroll Administration } \\
\text { Specialist, } \\
\text { Administration \& Payroll } \\
\text { Specialist, } \\
\text { HR Specialist Compensation } \\
\text { \& Benefits, } \\
\text { HR Advisor, } \\
\text { Contact Centre Advisor, } \\
\text { Recruitment Administrator, } \\
\text { Talent Sourcing Specialist }\end{array}$ & $\begin{array}{l}\text { Excellent language skills - fluent } \\
\text { English and good knowledge of } \\
\text { another given language: Dutch, } \\
\text { German, French, Hungarian, } \\
\text { Swedish, Norwegian, Finnish, } \\
\text { Italian, Portuguese, Russian, Arabic; } \\
\text { experience in HR (Recruitment / } \\
\text { Compensation / Benefits / Payroll / } \\
\text { HR Administration / Global Mobility); } \\
\text { Master's degree (HR, economy, law); } \\
\text { great problem-solving, decision- } \\
\text {-making and analytical skills; good } \\
\text { written and verbal communication } \\
\text { skills; experience working in } \\
\text { a multinational environment } \\
\text { (especially SSCs/BPO); advanced MS } \\
\text { Office skills; very good knowledge of } \\
\text { MS Outlook; knowledge of SAP or } \\
\text { another HR system; able to deal with } \\
\text { a high volume of work; ability to learn } \\
\text { new systems and solutions quickly; } \\
\text { ability to work independently and to } \\
\text { manage multi-tasks effectively with } \\
\text { minimal supervision }\end{array}$ \\
\hline
\end{tabular}


Table 3 cnt'd

\begin{tabular}{|c|c|c|}
\hline $\begin{array}{l}\text { Job Title } \\
\text { in HR SSCs }\end{array}$ & $\begin{array}{l}\text { Examples of Job Positions } \\
\text { in HR SSCs in Poland }\end{array}$ & $\begin{array}{l}\text { Required Qualities and Attributes } \\
\text { of Candidates for HR SSCs in Poland }\end{array}$ \\
\hline Senior Specialist & $\begin{array}{l}\text { Trainer Learning \& } \\
\text { Development Specialist, } \\
\text { Senior Payroll Specialist, } \\
\text { Personnel Specialist, } \\
\text { Payroll Global Process Owner, } \\
\text { Executive Assistant in HR } \\
\text { Projects, } \\
\text { Senior Recruiter, } \\
\text { HR UK Line Manager Advisor }\end{array}$ & $\begin{array}{l}\text { Fluent English / German; } \\
\text { communication skills; excellent MS } \\
\text { Office skills; very good analytical } \\
\text { skills; university degree (HR / } \\
\text { psychology / social science / finance, } \\
\text { economy, law); at least 2-3 years of HR } \\
\text { experience (Training \& Development } \\
\text { / Personal Administration and Payroll } \\
\text { / Recruitment); experience working } \\
\text { in an international SSC / BPO } \\
\text { environment; very good knowledge } \\
\text { of HR processes and policies; } \\
\text { knowledge of SAP; ability to } \\
\text { effectively prioritise and organise } \\
\text { workload, good at multitasking; very } \\
\text { good problem-solving, decision- } \\
\text {-making and analytical skills; good } \\
\text { written and verbal communication } \\
\text { skills; willing to relocate; excellent } \\
\text { networking and relationship-building } \\
\text { skills; trustworthy and a strong sense } \\
\text { of ownership }\end{array}$ \\
\hline Team Leader & $\begin{array}{l}\text { HR Associate Service Centre } \\
\text { Team Coordinator, } \\
\text { HR Vetting Leader, } \\
\text { Learning Coordinator, } \\
\text { Training Coordinator, } \\
\text { Talent Operations Team Lead, } \\
\text { Team Manager }\end{array}$ & $\begin{array}{l}\text { Minimum of } 2 \text { years' operational } \\
\text { management experience in an } \\
\text { international environment; fluency in } \\
\text { English / German; excellent written and } \\
\text { verbal communication skills; university } \\
\text { degree or relevant business experience; } \\
\text { key stakeholder and client management } \\
\text { experience at managerial level; proven } \\
\text { track record in delivering results to } \\
\text { an external client base through the } \\
\text { effective team management; experience } \\
\text { in engaging and motivating colleagues } \\
\text { to create a satisfying work environment; } \\
\text { high level of self-motivation and pro- } \\
\text {-activity; high orientation towards } \\
\text { quality, improvement and service; } \\
\text { ability to work under pressure and } \\
\text { meet tight deadlines; strong problem- } \\
\text {-solving and decision-making skills; } \\
\text { very good organisational and time } \\
\text { management skills; }\end{array}$ \\
\hline
\end{tabular}


Table 3 cnt'd

\begin{tabular}{|c|c|c|}
\hline \multirow[t]{2}{*}{$\begin{array}{c}\text { Job Title } \\
\text { in HR SSCs }\end{array}$} & $\begin{array}{l}\text { Examples of Job Positions } \\
\text { in HR SSCs in Poland }\end{array}$ & $\begin{array}{c}\text { Required Qualities and Attributes } \\
\text { of Candidates for HR SSCs in Poland }\end{array}$ \\
\hline & & $\begin{array}{l}\text { experience of working in an industry } \\
\text { relevant to customer service or HR } \\
\text { administration will be an asset; } \\
\text { experience in project / implementation } \\
\text { work would be an asset; spotless record } \\
\text { and a strong sense of ethos }\end{array}$ \\
\hline \multirow[t]{2}{*}{ Manager } & $\begin{array}{l}\text { Director of HR Associate } \\
\text { Service Centre }\end{array}$ & $\begin{array}{l}\text { University degree with a specialism; } \\
\text { a minimum of } 10 \text { years' job } \\
\text { experience (gained in HR SSCs, } \\
\text { BPO or Personnel); a minimum } \\
2 \text { years' experience in managing } \\
\text { big teams (more than } 20 \text { people) } \\
\text { in HR; experience of working in } \\
\text { a matrix structure; experience } \\
\text { of working as Personnel and } \\
\text { Payroll Manager in more complex } \\
\text { organisations; experience in planning, } \\
\text { streamlining, and shifting processes, } \\
\text { or organisation restructuring; ability } \\
\text { to build and manage big multi-task } \\
\text { teams; experience of ERP system } \\
\text { implementation; very good knowledge } \\
\text { of labour law and national insurance } \\
\text { regulations; very good people skills; } \\
\text { strategic thinking and decision-making } \\
\text { skills }\end{array}$ \\
\hline & HR Business Partner & $\begin{array}{l}\text { A degree required in Human } \\
\text { Resources Management or related } \\
\text { field; experience in an HR business } \\
\text { partner or HR manager role; } \\
\text { experience within a technology driven } \\
\text { environment; experience in managing } \\
\text { performance and assessing talent, } \\
\text { including executive talent; knowledge } \\
\text { of Polish employment / labour law; } \\
\text { fluent in Polish and English, both in } \\
\text { verbal and written communication, } \\
\text { including report writing skills; willing } \\
\text { to travel }\end{array}$ \\
\hline
\end{tabular}

Source: author's research based on HR job offers placed on a popular Polish recruitment website - www.pracuj.pl. On 31 March 2014 there were 797 job offers, including more than $10 \%$ in the SSC/BPO sector. 


\section{The Range of HR SSC Activities in Poland}

The transformations instigated by market globalisation, the internationalisation of economic activity and the free flow of intellectual capital mean that personnel officers are now facing entirely new challenges (Górska 2002, p. 95).

The HR Shared Service Centre is one of the outcomes of that transformation. As P. Reilly has pointed out, despite various local institutional and legal limitations, what companies are aiming for is to create a shared brand, to raise their organisational culture to the highest possible level, to standardise their HR strategy and operations and to introduce a global service model in which as much as possible of the HR department's work is outsourced to distant and cheap service centres (P. Reilly in Dawid-Sawicka 2011, p. 16).

In the terms of D. Ulrich's model (Ulrich 1997, p. 83), an SSC is a provider of HR services and an "administrative expert"; it is the place that consolidates the HR administration of various businesses using a number of different channels, such as web, telephone and e-mail. In rare cases, though, where an HR SSC is located near to the staff for which it provides services, face-to-face contact is possible in the form of support teams. Modern self-service solutions, such as HR web portals, self-service personnel portals and contact centres, which are platforms enabling staff (internal clients) to communicate with the HR SSC, also play a significant role. Employees can use them to check authorisations, update personal data, learn about the company's current payroll policy, confirm themselves as the beneficiaries of particular benefits and to print forms.

Specialists at HR SSCs draw up individual projects for groups of locations or for individual locations. The execution of personnel functions through such a centre may, for example, involve payroll reviews, payroll-policy monitoring, the mass amendment of remuneration data and position metrics (Banachowicz 2008, p. 313). Sample HR processes and types of personnel services rendered at Polish HR SSCs are set out in Table 4.

More often than not the tasks performed at HR SSCs are of a transactional nature. These are tasks that are performed en masse, that are easily automated, that follow binding procedures, that are homogenous and that involve similar processes and can therefore be standardised.

An example is provided by Schneider Electric's Polish HR SSC, which performs processes that are standardised for all entities and can be accomplished remotely using IT tools, such as a Human Resources 
Information System (HRIS), a help desk or an HR question-registration system. There are some highly complex processes, though, that require very specific skills acquired over many years, that depend highly on local laws and norms or that require a physical presence (e.g. a recruitment process) that cannot be allocated to a service centre (Kowalska \& Sobocińska 2011).

Table 4. The Scope of HR SSC Activity in Poland - Sample HR Processes and Types of Personnel Services

\begin{tabular}{l|l}
\hline Sample HR Processes in SSCs & \multicolumn{1}{|c}{ Sample Personnel Processes / Operations } \\
\hline Recruitment and selection & $\begin{array}{l}\text { Early stage of job interviews (CV-related activities); } \\
\text { job interview schedule; administration of qualification } \\
\text { tests; drafting contracts / agreements and introduction } \\
\text { to work }\end{array}$ \\
\hline Performance management & $\begin{array}{l}\text { Administration of employee assessments; processing } \\
\text { of performance results into a reward system }\end{array}$ \\
\hline Training and development & $\begin{array}{l}\text { Coordination and administration of learning and } \\
\text { development process: analysis of training needs; } \\
\text { planning, execution, and assessment of development } \\
\text { programmes; contracts with training companies / } \\
\text { internal trainers; designing and providing training; } \\
\text { training logistics management; eLearning; monitoring } \\
\text { and advice on training policies }\end{array}$ \\
\hline Payroll and benefits / & $\begin{array}{l}\text { Staff registration; administration of benefits; payroll } \\
\text { execution; application of Six Sigma methodology to } \\
\text { improve payroll processes }\end{array}$ \\
\hline Hompensation \& benefits & $\begin{array}{l}\text { HR administration management; drawing up personnel } \\
\text { documentation connected with recruitment and } \\
\text { the course of employment; registering holiday leave } \\
\text { applications and sick leave certificates; monitoring the } \\
\text { administration of personnel documentation }\end{array}$ \\
\hline Information System) & $\begin{array}{l}\text { Providing services for foreign employees (expatriates); } \\
\text { reimbursement of travel expenses; audit of travel costs }\end{array}$ \\
\hline Global mobility & $\begin{array}{l}\text { Assistance in computer-aided HRM; preparation } \\
\text { of standard reports; data entry }\end{array}$ \\
\hline Son &
\end{tabular}

Source: author's own research.

It should be noted that there are hardly any shared service centres devoted exclusively to HR: most are a good deal more wide ranging in the tasks they carry out. The most frequent of these at Polish business-service centres are finance and accounting, IT services, customer service and human resources management (Górecki 2013, p. 19). 


\section{Summary}

HR SSCs and HROs constitute a vital part of the developing sector of modern business services in Poland and the existing successful companies on the Polish market are attracting other investors. The German industrial concern ThyssenKrupp is planning to centralise financial, accounting and personnel services in the Gdańsk area (Tricity) at a centre that will employ 800 people over the next five years (Grzegorczyk 2014b).

The hypotheses advanced in the introduction have been successfully verified. In Poland, where investment comes predominantly from the EU and the USA, there are HR SSCs (e.g. UBS, Lufthansa, Shell) as well as HROs (e.g. Cox, Fitzsimons \& Wilkes, Devonshire, Modis International). The HR SSCs provide a variety of personnel services that mostly involve transaction processes, such as in recruitment and selection, performance management, training and professional development, payroll and benefits, HR administration, global mobility, and HRISs.

The establishment and development of HR SSCs and HROs in Poland is determined, above all, by labour costs and the quality of human capital; temporary factors are not taken into consideration. In addition to geographical location, incentives for foreign investors and the job market (including labour costs), the external determinants affecting the improved competitiveness of Polish HR SSCs and HROs also include the friendly and stable business environment and the thriving market for commercial property. The internal determinants of HR SSCs and HROs, meanwhile, are the quality of human capital and its management, which are factors that in the future may protect these entities against personnel risk and the risk that activities will be switched to locations where costs are lower.

There is a change underway in the SSC and BPO sector in Poland involving a transformation in the types of activities undertaken and the introduction of more advanced and creative services and processes. Does this trend extend to HR SSCs and HROs? Is the formula for HR SSCs and HROs in Poland going to change? There are no straightforward answers to these questions. Research carried out in the personnel departments of Polish companies (not at HR SSCs) has shown that routine activities prevail over creative ones in matters of personnel (Lipka, Król \& Winnicka-Wejs 2011). Transaction services are also prevalent in the HR departments of SSCs. What seems reasonably certain, however, is that changes in the human resources field are unavoidable and that investment in human capital and technology will be decisive in the further development of HR SSCs and HROs in Poland. 


\section{Bibliography}

Adamkiewicz-Drwiłło, H. G. (2010) Konkurencyjność przedsiębiorstw w świetle uwarunkowań wspótczesnej gospodarki [Enterprise competitiveness in light of modern economic conditions]. Toruń: Wydawnictwo "Dom Organizatora”.

Banachowicz, E. (2008) "Centra usług wspólnych. Stan obecny i perspektywy rozwojowe" [Shared service centres] in A. Szymaniak (ed.) Globalizacja ustug. Outsourcing, offshoring $i$ shared services centers [The globalisation of services. Outsourcing, offshoring, and shared services centers]. Warsaw: Wydawnictwa Akademickie i Profesjonalne.

Chojnowska-Haponik, I. (2013) "Inwestycje zagraniczne w Polsce w 2012 r. Perspektywy napływu BIZ do Polski w 2013 r." [Foreign investment in Poland in 2012. Prospects for FDI inflows to Poland in 2013]. Warsaw: Polish Information and Foreign Investment Agency, 17 January 2013, www.paiz.gov.pl/files/?id_plik=19366, date of access: 24 March 2014.

Corbett, M. F. (2004) The Outsourcing Revolution. Why It Makes Sense and How to Do It Right. Chicago: Dearborn Trade Publishers.

Czuba, A. (2013) "Outsourcing w Polsce rozwija się coraz lepiej. Powód? Wyszkolone kadry" [Outsourcing in Poland is forging ahead. The reason? Highly-qualified staff], http://biznes.newsweek.pl/outsourcing-w-polsce-rozwija-sie-coraz-lepiej--powod-wyszkolone-kadry,107856,1,1.html, date of access: 31 August 2013.

Dawid-Sawicka, M. (2011) "Reilly: HR musi pomagać w rozwiązywaniu problemów biznesowych" [Reilly: HR must help in solving business problems]. Personel Plus 05 (42).

European Economic Congress (2013). Programme. Katowice, 13-15 May.

Ewing, J. (2013) "Midsize Cities in Poland Develop as Service Hubs for Outsourcing Industry", http://www.nytimes.com/2013/12/23/business/international/midsize-cities-inpoland-develop-as-service-hubs-for-outsourcing-industry.html?_r=0, date of access: 23 December 2013.

Górecki, J. (2013) "Charakterystyka sektora nowoczesnych usług biznesowych w Polsce" [Characteristics of the modern business service sector in Poland] in J. Górecki, M. Jasińska, M. Polkowski and Ł. Karpiesiuk Sektor nowoczesnych ustug biznesowych $w$ Polsce 2013 [The modern business service sector in Poland 2013]. Warsaw: Associaton of Business Service Leaders in Poland (ABSL) in cooperation with Hays Poland, Jones Lang LaSalle, and Baker\&McKenzie.

Górecki, J., Jasińska, M., Szreder, T., Polkowski, M. and Karpiesiuk, Ł. (2012) Sektor nowoczesnych ustug biznesowych $w$ Polsce [The modern business service sector in Poland]. Warsaw: Association of Business Service Leaders in Poland (ABSL) in cooperation with Hays Poland, Jones Lang LaSalle, and Baker\&McKenzie.

Górska, J. (2002) "Outsourcing jako metoda zarządzania przedsiębiorstwem" [Outsourcing as a method of enterprise management] in A. Ludwiczyński (ed.) Najlepsze praktyki zarzadzania kapitatem ludzkim [Best practices in managing human capital]. Warsaw: Polish Foundation for Management Promotion.

Grzegorczyk, M. (2014a) "Centra usług wyprzedziły kopalnie" [Service centres ahead of mines], http://www.pb.pl/3539435,5112,centra-uslug-wyprzedzily-kopalnie, date of access: 30 January 2014. 
Grzegorczyk, M. (2014b) “ThyssenKrupp zatrudni 800 osób” [ThyssenKrupp to employ 800 people], http://www.pb.pl/3607740,28691,thyssenkrupp-zatrudni-800-osob, date of access: 27 March 2014.

Jasińska, M. (2013) "Rynek pracy" [The jobs market] in J. Górecki, M. Jasińska, M. Polkowski and Ł. Karpiesiuk Sektor nowoczesnych ustug biznesowych w Polsce 2013 [The modern business service sector in Poland 2013]. Warsaw: Associaton of Business Service Leaders in Poland (ABSL) in cooperation with Hays Poland, Jones Lang LaSalle, and Baker\&McKenzie.

Kalinowski, J., Pawlicki, G., Kolczyński, Ł., Strojny, M., Żagun, K., Mańkowski, M., Miszkin, M., Klimczak, D. and Kuskowski, P. (2009) "Poland as the Destination for Shared Service Centers". Warsaw: KPMG, www.kpmg.com, date of access: 17 May 2011.

Klimek-Michno, K. (2012) “Zewnętrzna obsługa. Outsourcing funkcji personalnych sposobem na kryzys" [External services. The outsourcing HR functions as a way to solve the crisis]. Personel $i$ Zarzadzanie 3 (264).

Kossowska, M., Górniak, J., Prokopowicz, P., Żmuda, G., Malinowska, D., Pyrkosz, J., Jaśko, K., Król, M. and Baryła, B. (2012) "Bilans kompetencji branż BPO i ITO w Krakowie. Raport końcowy z przeprowadzonych badań" [Skills assessment in in BPO and ITO in Kraków]. Kraków: Jagiellonian University Centre for the Evaluation and Analysis of Public Policies and the Jagiellonian University Interdisciplinary Centre for Organisational Research and Development, September.

Kowalska, E. and Sobocińska, T. (2011) "Centra przyszłości" [Centres of the future]. Personel i Zarzadzanie 4 (253).

Lipka, A., Król, M. and Winnicka-Wejs, A. (2011) Kreatywnośc i rutyna $w$ dziatalności personalnej. Granice HR-owego kreacjonizmu [Creativity and routine in HR activities. The limits of HR-related creationism. Warsaw: Difin.

Majchrzak, M. (2012) Konkurencyjność przedsiębiorstw podsektora ustug biznesowych $w$ Polsce. Perspektywa mikro-, mezo- i makroekonomiczna [Enterprise competitiveness in the business services subsector in Poland. A micro-, mezo-, and macroeconomic perspective]. Warsaw: CeDeWu.

Micek, G., Działek, J. and Górecki, J. (2010) Centra ustug w Krakowie i ich relacje $z$ otoczeniem lokalnym [Service centres in Kraków and their relationship with the local environment]. Kraków: Jagiellonian University Press.

Michalska-Sabal, A., Chrześcijanek, A., and Guzik. E. (eds) (2013) Sektor ustug biznesowych w Matopolsce. Stan i perspektywy rozwoju [The business service sector in Małopolska. Current state and development prospects]. Kraków: Regional Labour Office. Labour Market and Education Observatory of Małopolska.

Oczkowska, R. (2012) "Offshoring jako szansa wykorzystania globalnych zasobów kapitału ludzkiego" [Offshoring as an opportunity to use global human capital resources] in M. G. Woźniak (ed.) Nierówności spoteczne a wzrost gospodarczy [Social inequalities and economic growth]. Rzeszów: Rzeszów University, Department of Economic Theory and International Relations.

Onshore (2013) "Onshore, Nearshore, Offshore: Unsure? A 2013 Polish Perspective". Jones Lang LaSalle, Association of Business Service Leaders, Polish Information and Foreign Investment Agency, Hays Specialist Recruitment, June.

Pniewski, K. (2008) "Od decyzji do implementacji: praktyczne aspekty budowy centrum usług księgowych" [From decision to implementation. Practical aspects of building 
accounting services centres] in A. Szymaniak (ed.) Globalizacja ustug. Outsourcing, offshoring $i$ shared services centers [The globalisation of services. Outsourcing, offshoring, and shared services centers]. Warsaw: Wydawnictwa Akademickie i Profesjonalne.

Radło, M. J. (2011) "Kontrakty outsourcingowe" [Outsourcing contracts] in D. Ciesielska and M. J. Radło (eds) Outsourcing w praktyce [Outsourcing in practice]. Warsaw: Wydawnictwo Poltext.

Szydłowska, K. (2008) "Ceny transferowe a zagadnienie centrów usług wspólnych" [Transfer pricing and the issue of shared service centres] in A. Szymaniak (ed.) Globalizacja ustug. Outsourcing, offshoring $i$ shared services centers [The globalisation of services. Outsourcing, offshoring, and shared services centers]. Warsaw: Wydawnictwa Akademickie i Profesjonalne.

Szablewski, A. (ed.) (2009) Migracja kapitatu w globalnej gospodarce [Capital migration in the global economy]. Warsaw: Difin.

Ulrich, D. (1997) Human Resource Champions. The Next Agenda for Adding Value and Delivering Results. Cambridge, MA: Harvard Business School Press.

Winnicka-Wejs, A. and Klich, A. (2011) "Rozwój HR Shared Service Centers w Polsce" [The development of HR shared service centers in Poland" in M. Ćwiklicki and M. Jabłoński (eds) Konsulting dla organizacji gospodarczych i niezorientowanych na zysk [Consulting for economic and non-for-profit organisations]. Kraków: Kraków University of Economics Foundation.

Ziółkiewicz, M. (2010) "Rola Polski w rozwoju outsourcingu usług z kręgu BPO" [Poland's role in the development of BPO". e-Finanse 6 (4).

Zorska, A. (2007) "Outsourcing i przenoszenie usług na świecie. Wnioski dla Polski" [Outsourcing and the movement of services worldwide]. Gospodarka Narodowa 1-2: $33-57$.

\section{Abstract}

\section{Temporalne, kosztowe i jakościowe aspekty funkcjonowania HR SSC/HRO w Polsce}

W opracowaniu scharakteryzowano dynamicznie rozwijający się sektor nowoczesnych usług biznesowych w Polsce, ze szczególnym uwzględnieniem HR shared service centres (HR SSC) i HR outsourcing (HRO). Zaprezentowano temporalne, kosztowe i jakościowe aspekty funkcjonowania HR SSC/HRO w Polsce, wyróżniając egzogeniczne i endogeniczne uwarunkowania ich konkurencyjności. Ponadto wskazano zakres działalności HR SSC/HRO w Polsce. Na potrzeby opracowania postawiono cztery hipotezy badawcze, które zweryfikowano za pomocą głównej metody badawczej, jaką była analiza i krytyczna ocena dostępnej literatury przedmiotu i raportów branżowych.

Słowa kluczowe: sektor nowoczesnych usług dla biznesu w Polsce, HR centra usług wspólnych (HR SSC), HR centra outsourcingu (HRO), konkurencyjność polskich HR SSC/HRO. 